\title{
The Phillips Curve in Portugal
}

Agostinho Silvestre Rosa*

Abstract: This paper estimates the Phillips curve in Portugal using the Johansen Method, with the wage inflation rate as a dependent variable, based on annual data from the period 1954-1995. The main conclusions are as follows. Firstly, in the long term, the wage inflation rate relates positively to the inflation rate and negatively to the unemployment rate, as expected. There is also a positive relationship between the wage inflation rate and the average labour productivity growth index. Secondly, in the short term, the variation of the wage inflation rate relates negatively and significantly to the error correction mechanism with a negative unitary coefficient; therefore, there is a quick and significant response to the equilibrium error between the wage inflation rate and its determinants. Besides this adjustment, the wage inflation rate responds positively to a lagged wage inflation rate. The variation in the unemployment rate and the average labour productivity growth present the expected signal, negative and positive respectively, but without significance in the short term. The dummy that refers to the April 1974 revolution is significant.

Keywords: Phillips curve. Unit roots. Cointegration.

Resumo: A estimação da curva de Phillips para Portugal, utilizando a taxa de crescimento dos salários nominais como variável dependente, com base em dados anuais do período 1954-1995, usando o método de Johansen, permite-nos concluir duas coisas: primeiro, que, a longo prazo, a taxa de crescimento dos salários nominais relaciona-se positivamente com a taxa de inflação e negativamente com a taxa de desemprego, como era esperado. Há também uma relação positiva entre a taxa de crescimento dos salários nominais e o índice de crescimento da produtividade média do trabalho; segundo, que, a curto prazo, a variação do crescimento dos salários nominais relaciona-se negativa e significativamente com o mecanismo corrector do erro com um coeficiente unitário negativo e, por conseguinte, há uma resposta rápida e significativa ao erro de equilíbrio entre a taxa de crescimento dos salários nominais e os seus determinantes. Além desse ajustamento, a taxa de crescimento dos salários nominais responde positivamente a uma taxa de crescimento dos salários nominais desfasada. A variação da taxa de desemprego e o crescimento da produtividade média do trabalho apresentam o sinal esperado,

Department of Economics, University of Évora, Portugal, and Center for Advanced Studies in Management and Economics of the University of Évora, (CEFAGE-UE). E-mail: arosa@uevora.pt I am grateful to an anonymous referee and to my colleague Fernanda Peixe. However, any error or omission is solely my responsibility. 
negativo e positivo, respectivamente, mas sem significado a curto prazo. A dummy que se refere à revolução de abril de 1974 é significativa.

Palavras-chave: Curva de Phillips. Raízes unitárias. Cointegração.

JEL Classification: C12; C32; E24; E31.

\section{Introduction}

The original Phillips curve describes an empirical relationship between wage inflation and unemployment according to Phillips (1958). Lipsey (1960) introduces the theoretical fundaments of that curve and Samuelson and Solow (1960) apply the more common modification: the relation between the inflation rate and the unemployment rate. This relationship was greatly used in the 1960 s by policy-makers. The trade-off between inflation and unemployment was recommended to economic policy makers as an instrument that would allow them to formulate policy programmes with alternative combinations of unemployment and inflation rate.

The Oil Shock in the 1970s raised problems to that theory, because there was unemployment together with increasing inflation. Friedman (1968) and Phelps (1967) introduced expectations in the original Phillips curve to take account of expected inflation.

Our objective is to estimate a wage Phillips curve to Portugal. We can say that the three main factors influencing wage negotiation and driving the rate of growth of nominal wages are inflation expectations, productivity growth and the state of demand in the labour market.

The Inflation taken in account during wage negotiations has a backward-looking (catching up with past inflation) and a forward-looking component (what inflation is expected to be in the future). The long term corresponds to the time it takes for this inflation and actual inflation to catch up with each other. So, in the long term the actual inflation rate can be used as a proxy to the expected inflation. In the short term, with uncertainty about the future, the employees tried to protect their wages against past inflation, so the lagged inflation rate can be used as expected inflation.

If the productivity increases, the wages can rise without any increase in unit labour cost. In our model, we can expect a positive impact of productivity growth on wages. The state of demand in the labour market can be measured by the unemployment rate. When the unemployment rate is above the equilibrium rate of unemployment, wages tend to slow down, and vice-versa. In our model, we can expect a negative relationship between the rate of growth of nominal wages and the unemployment rate. So, we have: 


$$
\dot{W}=f\left(\stackrel{(-)}{U}, \stackrel{(+)}{P^{e}}, \stackrel{(+)}{\dot{Q}}\right)
$$

where $W$ is the money wage rate, $U$ the unemployment rate, $P^{e}$ the inflation expectations and $Q$ the average labour productivity growth.

\section{Data and Stationarity Analysis}

Campbell and Perron (1991), gives the justification to the use of annual data, either because stationarity analysis needs a wide time span, or "seasonal adjustment procedures often create a bias toward nonrejection of a unit root hypothesis". Four annual variables for the period 1954-95 were selected: $W$, money wages rate; $P$, inflation rate; $\mathrm{U}$, unemployment rate; $Q$, average labour productivity growth.

The data source is Pinheiro et al. (1999), except for the inflation rate, whose source is CPI, estimated by INE.

The Dickey-Pantula (1987) test allows us to reject the null hypothesis of I(2) in all variables studied. Applying the $\mathrm{ADF}$ test, the variables $W, \mathrm{U}, \dot{P}$ are $\mathrm{I}(1)$, and the variable $Q$ is I(0). Using the DF-GLS test of Elliot, Rothemberg and Stock (1996), with a k-max $=12$ and the MAIC ${ }^{1}$ criterion, and using the Perron and Vogelsang (1992) test with endogenous choice of the break point (Tb), with the endogenous selection of $k$ described by Perron (1997), we can reach the same conclusion. The unit root test with endogenous choice of the break point select a break point at the beginnings of the 70's. So, we used the Perron (1990) test with exogenous choice of the break point at 1974, year of the April revolution in Portugal, and we get the same conclusion, except for the unemployment rate: if we use the innovational outlier model, the unemployment rate is I(0), but if we use the additive outlier model, the I(1) result cannot be rejected at $5 \%$. So, we add to our model a dummy variable (Dum74, assumes value 1 in 1974), to take into account the April revolution.

\section{Estimation of a Phillips Curve Model}

The Johansen method is used because it allows the detection of the presence of more than one cointegrating vector. There are stationary regressors in the VAR model, so we follow the methodology of Rahbek and Mosconi (1999), which consists of adding to the VAR the cumulated explanatory I(0) variables as I(1) exogenous variables, and thus the critical values of the trace or eigenvalue tests of,

AIC criterion modified by Ng and Perron (2001). 
among other authors, Pesaran, Shin and Smith (2000) can be used. ${ }^{2}$ First, as we have exogenous variables, the cointegrated VAR model to use corresponds to the conditional model:

$$
\Delta Y_{t}=\mu_{c}+\delta_{c} t+\sum_{i=1}^{k-1} \Psi_{i} \Delta X_{t-i}+\Pi_{y} X_{t-1}+\omega \Delta Z_{t}+\varepsilon_{c t}
$$

where $X_{t}$ is a Nx1 vector of $I(1)$ variables, which we can divide into $N_{y}$ endogenous I(1) variables (Y) and $\mathrm{N}_{z}$ exogenous I(1) variables (Z) , such that $N_{y}+N_{z}=N . \Pi_{y}$ is the long-run multiplier matrix of order $\left(\mathrm{N}_{\mathrm{y}} \mathrm{xN}\right)$ given by $\Pi_{y}=\alpha_{y} \beta^{\prime}$, where $\alpha_{\mathrm{y}}$ is a $\left(\mathrm{N}_{\mathrm{y}} \mathrm{xr}\right)$ matrix and $\beta$ a (Nxr) matrix of $\mathrm{r}$ cointegrating vectors.

The null hypothesis of the cointegration rank (existence of $r$ cointegrating vectors) is written:

$$
\mathrm{Hr}: \mathrm{R}\left[\Pi_{y}\right]=r, \quad \mathrm{r}=0, \ldots, \mathrm{N}_{\mathrm{y}} ;
$$

where " $\mathrm{R}$ " is the rank of the matrix.

In the estimation of the conditional model, we can consider 5 cases (or models) consonant with the restrictions imposed on the deterministic terms, in accordance with PSS (2000).

\subsection{Estimation of the Long-Term Model}

Initially, the model had three endogenous I(1) variables ( $W, \mathrm{U}, P$ ), and one exogenous I(0) variable $(Q)$. We selected VAR(3), so that the estimated residuals satisfies Johansen (1996) recommendations. We cannot reject the weak exogeneity of the unemployment rate in the models II to IV from PSS (2000) at $5 \%$ level. The model with two endogenous I(1) variables ( $W$ and $P$ ), one I(1) exogenous variable $(\mathrm{U})$, one I(0) variable $(Q)$ and a dummy Dum74, following Rahbek and Mosconi (1999), was estimated: $\dot{W} \dot{P} ; U \operatorname{csum} \dot{Q} \& \Delta U \dot{Q}$ Dum 74 , where there are two endogenous I(1) variables $(W, P)$ and two exogenous I(1) variables $(U, \operatorname{csum} Q)$. The variable $\operatorname{csum} Q$ is the cumulative sum of $Q$.

Given VAR(3), the methodology of PSS (2000) leads us to choose model III. The existence of one cointegrating vector cannot be rejected, either by the trace test, or by the maximum eigenvalue test. The AIC, SBC and HQC criterions also select the model with $\mathrm{r}=1$. The vector normalized in relation to $W$ (and identified) without restrictions with $X_{t}^{\prime}=[\dot{W} \dot{P} U \operatorname{csum} \dot{Q}]$ is given by: ${ }^{3}$

Referred to as PSS (2000), afterwards

Between round brackets in the cointegrating vector are standard errors. 


$$
\beta^{\prime}=\left[\begin{array}{cccc}
1 & -0.53402 & 0.83804 & -0.07426 \\
& (0.09235) & (0.96643) & (0.01524)
\end{array}\right]
$$

Applying the likelihood ratio test, the hypothesis $\beta_{4}=0$ is rejected at $1 \%$; this means that the average labour productivity growth index is into the cointegrating vector. The hypothesis $\beta_{3}=0$ is rejected at $6 \%$; this means that the unemployment rate must remain included in the cointegrating vector. As was expected, the hypothesis $\beta_{2}=0$ is rejected, at $1 \%$ level. Thus, the wage inflation rate relates positively to the inflation rate and negatively to the unemployment rate. There is also a positive relation between wage inflation and the average labour productivity growth index.

The actual Macroeconomic Theory postulate that the real variables do not influence nominal variables and vice-versa, except on the short term because of the price and wage stickiness (new Keynesian theory) or due to not anticipate policies (new classical theory). Therefore, the long term Phillips curve would be vertical at the natural rate of unemployment, which means no relationship between inflation and unemployment.

In our study, the estimated wage Phillips curve has a long term relationship between wage inflation, unemployment rate and inflation rate. The explanation for this can be given by the Keynesian economists (see TOBIN, 1972), who accept that exist some long term trade-off even when expected inflation has fully adjusted to actual inflation. This means that there is some money illusion. As we can see, the estimated coefficient of $P$ is less than 1.0, so when $P$ increases, $W$ increases only more or less $50 \%$ of $P$, therefore the real wage decreases. In this case real wage falls as a result of the increase in inflation rate and the firms can hire more workers without loss in profit. The employment must rise, so the monetary policy may have real effect even in the long term.

\subsection{Estimation of the Short-Term Model}

The variation of the wage inflation rate (Table 1 ) relates negatively and significantly at $1 \%$ level to the error correction mechanism (ECM1) with a negative unitary coefficient; therefore, there is a quick and significant response to the long-term disequilibria. Besides this adjustment, the wage inflation rate responds positively to a lagged wage inflation rate. Both the variation of the unemployment rate and the average labour productivity growth present the expected signal, but without significance level. The dummy Dum74 is significant at $1 \%$.

The variation of the inflation rate relates positively and significantly at $1 \%$ to the error correction mechanism. It presents a negative and significant relation at $1 \%$ to the variation of the lagged wage inflation rate $\left(\Delta W_{t-1}\right)$. So, this relation can 
mean that the inflation rate responds more to two-period lagged unit labour costs than to one.

The diagnostic tests indicate that, in both equations, residuals satisfy Johansen (1996) recommendations. We cannot reject correct specification of the model in the $\Delta \dot{W}$ equation, but we can do that in the $\Delta \dot{P}$ equation at $10 \%$ significant level. The low $\overline{R^{2}}$ in the $\Delta P$ equation also means that we need more explanatory variables in relation to the inflation rate, but our objective is to estimate the Phillips curve with $W$ as a dependent variable, so we do not increase the number of variables.

Table 1 - Multivariate model

\begin{tabular}{|c|c|c|}
\hline E qua tion/Regressor & $\Delta \mathbf{W}$ & $\Delta \dot{\mathrm{P}}$ \\
\hline No. Observations & $\begin{array}{c}\mathrm{T}=39 \\
{[57-95]}\end{array}$ & $\begin{array}{c}\mathrm{T}=39 \\
{[57-95]}\end{array}$ \\
\hline $\begin{array}{l}\text { Intercept } \\
\Delta \mathrm{W}(-1)\end{array}$ & $\begin{array}{l}4.3676[.041] \\
.53214[.002]\end{array}$ & $\begin{array}{l}-5.9103[.005] \\
-.59261[.000]\end{array}$ \\
\hline$\Delta \dot{\mathrm{P}}(-1)$ & $0.014023[.929]$ & $-.13396[.373]$ \\
\hline $\begin{array}{l}\Delta U(-1) \\
\dot{Q}(-1)\end{array}$ & $\begin{array}{l}-.96032[.345] \\
-.30739[.240]\end{array}$ & $\begin{array}{l}.30054[.753] \\
.45980[.069]\end{array}$ \\
\hline$\Delta \mathrm{W}(-2)$ & $.29989[.073]$ & $-.18522[.235]$ \\
\hline$\Delta \dot{\mathrm{P}}(-2)$ & $-.15917[.335]$ & $.10644[.494]$ \\
\hline$\Delta U(-2)$ & $\begin{array}{l}1.7011[.074] \\
.20576[.480]\end{array}$ & $\begin{array}{l}-1.5145[.092] \\
.087955[.749]\end{array}$ \\
\hline $\begin{array}{l}Q(-2) \\
\operatorname{ECMl}(-1)\end{array}$ & $-1.0044[.000]$ & $.59508[.006]$ \\
\hline$\Delta U$ & $-.76496[.480]$ & $.061584[.952]$ \\
\hline Q & $.25871[.270]$ & $.17795[.421]$ \\
\hline $\begin{array}{l}\text { DUM } 74 \\
\overline{\mathrm{R}}^{2}\end{array}$ & $\begin{array}{r}15.9797[.000] \\
.64172\end{array}$ & $\begin{array}{r}13.8574[.001] \\
.44907\end{array}$ \\
\hline SEE & 3.3839 & 3.2066 \\
\hline $\operatorname{LM}(1,25)$ & $.76209[.391]$ & $1.9750[.172]$ \\
\hline $\operatorname{RE} \operatorname{SET}(1,25)$ & $.071591[.791]$ & $3.1194[.090]$ \\
\hline $\mathrm{BJ}(2)$ & $.12983[.937]$ & $2.0168[.365]$ \\
\hline HE T $(1,37)$ & $1.0145[.314]$ & $31377[.579]$ \\
\hline $\operatorname{ARCH}(3,23)$ & $1.2875[.302]$ & $1.1021[.368]$ \\
\hline
\end{tabular}

Source: Calculations were performed by the author.

The parsimonious model (Table 2) was estimated using the Wald test on the joint nullity of its coefficients, and removing from the $\Delta \dot{W}$ equation all the variables not significant at $5 \%$ level. The parsimonious model is $\Delta \dot{W}=f\left(\right.$ inpt $, \Delta \dot{W}_{t-1}, E C M 1_{t-1}$, Dum 74$)$. The estimation of the $\Delta \dot{W}$ equation with these regressors (W1 equation - Table 2) presents all the coefficients significant at $1 \% . \Delta W$ is a function of the lagged variation in money wages rate, of the ECM 1 (long-term relationship between $W$ and the other variables), and also of the Dum74 (which is, either the effect of the April revolution, or the first Oil shock).

We estimate the parsimonious model without the Dum74 (W2 equation) to make a comparison with the same model estimated in the period 1956-90 (W3 equation), where we cannot reject either the predictive capacity after 1990 or the structural stability before and after 1990.

The $\Delta \dot{W}$ equations estimated with or without Dum74 for the period post $25^{\text {th }}$ April (1974-1995) [W4 and W5 equations], have, more or less, the same coefficients estimated for the whole period. In this period, post $25^{\text {th }}$ April 1974, we can- 
not reject either the predictive capacity after 1990 or the structural stability before and after 1990 (W6 equation).

In all the estimated equations, we can verify the coefficient stability as the Chow (1960) tests suggest. The coefficient of $\Delta \dot{W}_{t-1}$ varies between 0.33 and 0.47 through the six equations, being higher in the period post-1974. The coefficient of $\mathrm{ECM1}_{\mathrm{t}-1}$ is more stable, varying between 0.75 and 0.85 . The change of period does not influence this coefficient.

In both equations of the multivariate model and, in all equations of the parsimonious model, CUSUM and CUSUMSQ tests do not cross any of the significant bars at $5 \%$ level.

Table 2 - Parsimonious Equations of $\Delta \dot{W}$

\begin{tabular}{|c|c|c|c|c|c|c|}
\hline $\begin{array}{l}\text { Equation/ } \\
\text { Regressor }\end{array}$ & $\begin{array}{c}\mathrm{W} 1 \\
\mathrm{~T}=40 \\
{[56-95]} \\
\end{array}$ & $\begin{array}{c}\mathrm{W} 2 \\
\mathrm{~T}=40 \\
{[56-95]} \\
\end{array}$ & $\begin{array}{c}\mathrm{W} 3 \\
\mathrm{~T}_{1}=35, \mathrm{~T}_{2}=5 \\
{[56-90]}\end{array}$ & $\begin{array}{c}\mathrm{W} 4 \\
\mathrm{~T}=22 \\
{[74-95]} \\
\end{array}$ & $\begin{array}{c}\text { W5 } \\
T=22 \\
{[74-95]} \\
\end{array}$ & $\begin{array}{c}\mathrm{W} 6 \\
\mathrm{~T}_{1}=17, \mathrm{~T}_{2}=5 \\
{[74-90]}\end{array}$ \\
\hline Intercept & $3.6471[.000]$ & $4.3681[.000]$ & $4.9016[.000]$ & $2.9202[.037]$ & $4.1253[.023]$ & 5.0382[.027] \\
\hline$\Delta W(-1)$ & $.33241[.009]$ & $.40450[.010]$ & $.36421[.021]$ & $.37602[.026]$ & $.47035[.032]$ & $.43366[.070]$ \\
\hline $\operatorname{ECM} 1(-1)$ & $-.76629[.000]$ & $-.82509[.000]$ & $-.84459[.000]$ & $-.75006[.000]$ & $-.82374[.001]$ & $-.85048[.003]$ \\
\hline DUM74 & $16.7290[.000]$ & - & - & $7.2569[.001]$ & - & \\
\hline$\overline{R^{2}}$ & .59786 & .37625 & .40710 & .64626 & .37469 & .39438 \\
\hline SEE & 3.5399 & 4.4087 & 4.3893 & 4.2164 & 5.6060 & 6.0025 \\
\hline $\mathrm{LM}(1, \mathrm{~T}-\mathrm{k}-1)$ & $.079543[.780]$ & $.50482[.482]$ & $1.0511[.313]$ & $.064645[.802]$ & $.86204[.365]$ & $.96901[.343]$ \\
\hline $\operatorname{RESET}(1, \mathrm{~T}-\mathrm{k}-1)$ & $.21887[.643]$ & $.21563[.645]$ & $.021748[.884]$ & $.81355[.380]$ & $.40973[.530]$ & $.96901[.343]$ \\
\hline $\mathrm{BJ}(2)$ & $7.7543[.021]$ & $28.1691[.000]$ & $34.4635[.000]$ & $1.5258[.466]$ & $7.0862[.029]$ & $4.2406[.120]$ \\
\hline $\operatorname{HET}(1, T-2)$ & $.63092[.432]$ & $.29351[.591]$ & $.16225[.690]$ & $1.0487[.318]$ & $.61915[.441]$ & $.59171[.454]$ \\
\hline $\mathrm{ARCH}(2, \mathrm{~T}-\mathrm{k}-2)$ & $.13564[.874]$ & $.31824[.730]$ & $.28948[.751]$ & $.18444[.833]$ & $.35155[.709]$ & $.26035[.775]$ \\
\hline $\operatorname{Chow}\left(\mathrm{T}_{2}, \mathrm{~T}_{1}-\mathrm{k}\right)$ & - & - & $1.0654[.398]$ & - & - & $.51446[.761]$ \\
\hline $\operatorname{Cov}\left(k, T_{1}+T_{2}-2 k\right)$ & - & - & $1.5549[.218]$ & - & - & $.78730[.518]$ \\
\hline
\end{tabular}

Source: Calculations were performed by the author.

Notes: Estimation Method: $E C M 1=\dot{W}-0.53402 \dot{P}+0.83804 U-0.074256$ csum $\dot{Q}$. Between square brackets: $\mathrm{p}$-value or sample period (on the top). On the estimated coefficients Ho: $\beta=0$. Diagnostic tests: LM - statistic of Lagrange Multiplier test for serial correlation; RESET - statistic of Ramsey's RESET test for functional form misspecification; BJ - statistic of Jarque-Bera's test of normality; HET - statistic of Heteroscedasticity test; $\mathrm{ARCH}$ - statistic of ARCH test [Engle's test]; Chow-statistic of Predictive failure test ( $2^{\text {nd }}$ test of Chow); Cov - statistic of Chow's test of stability of regression coefficients ( $1^{\text {st }}$ test of Chow).

\section{Final Considerations}

In the long term, the wage inflation rate relates positively to the inflation rate and negatively to the unemployment rate, as was expected. There is also a positive relationship between the wage inflation rate and the average labour productivity growth index. 
In the short term, the variation of the wage inflation rate relates negatively and significantly to the error correction mechanism with a negative unitary coefficient. Therefore, there is a quick and significant response to the equilibrium error between wage inflation rate and its determinants (inflation rate, unemployment rate and average labour productivity growth index). As well as this adjustment, the wage inflation rate responds positively to a lagged wage inflation rate. The variation of the unemployment rate and the average labour productivity growth present the expected signal, negative and positive respectively, but without significance. The dummy that refers to the April 1974 revolution is significant. We can have a parsimonious model as a relationship between the wage inflation rate, the lagged wage inflation rate, the error correction mechanism and the dummy that refers to the April 1974 revolution.

\section{References}

CAMPBEL, J. Y.; PERRON, P. Pitfalls and Opportunities: What Macroeconomics Should Know about Unit Roots. In NBER Macroeconomics Annual, p.141-201, 1991.

DICKEY, D. A.; PANTULA, S. G. Determining the Order Differencing in Autoregressive Processes. Journal of Business and Economic Statistics, v. 5, n. 4, p. 455-461, 1987.

ELLIOT, G.; ROTHEMBERG, T. J.; STOCK, J. H. Efficient tests for an autoregressive unit root. Econometrica, v. 64, n. 4, p. 813-836, 1996.

FRIEDMAN, M. The Role of Monetary Policy. American Economic Review, v. 58, n. 1, p. 1-17, 1968.

JOHANSEN, S. Likelihood-based inference in cointegration vector autoregressive models. Oxford: Oxford University Press, 1996.

LIPSEY, R. G. The relation between unemployment and the rate of change of money wage rates in the United Kingdom, 1862-1957: a further analysis. Economica, v. 27, n. 105, p. 1-31, 1960.

NG, S.; PERRON, P. A note on the selection of time series models. Boston: Boston College, Departament of Economics, 2001. (WP n ${ }^{\circ} 500$ ).

PERRON, P. Further evidence on breaking trend functions in macroeconomic variables. Journal of Econometrics, v. 80, n. 2, p. 355-385, 1997.

Testing for a unit root in a time series with a changing mean. Journal of Business and Economic Statistics, v. 8, n. 2, p. 153-162, 1990.

PERRON, P.; VOGELSANG, T. J. Nonstationarity and level shifts with an application to purchasing power parity. Journal fo Business and Economic Statistics, v. 10, n. 3, p. 301-320, 1992.

PESARAN, M. H.; SHIN, Y.; SMITH, R. J. Structural analysis of vector error correction models with exogenous I(1) variables. Journal of Econometrics, v. 97, n. 2, p. 293-343, 2000.

PHELPS, E. S. Phillips curves, expectations of inflation and optimal unemployment over time. Economica, v. 34, p. 254-81, 1967. 
PHILLIPS, A.W. The relation between unemployment and the rate of change of money wage rates in the United Kingdom, 1861 - 1957. Economica, v. 25, n. 100, p. 283-299, 1958.

PINHEIRO, M. et al. Historical Series for the Portuguese Economy - Post II World War. Bank of Portugal, 1999. Available in: <www.bportugal.pt>. Access in: January 28th, 2006.

RAHBEK, A.; MOSCONI, R. Cointegration Rank Inference with Stationary Regressors in VAR Models. Econometrics Journal, v. 2, p. 76-91, 1999.

SAMUELSON, P.; SOLOW, R. Problem of achieving and maintaining a stable price level: analytical aspects of anti-inflation policy. American Economic Review, v. 50, n. 2, p. 177-194, 1960.

TOBIN, J. Inflation and Unemployment. American Economic Review, v. 62, n. 1, p. 1-18, 1972.

Recebido em: 18/06/2012.

Aceito em: 12/05/2013. 